\title{
The physico-chemical and sensory properties of jackfruit (artocarpus heterophilus) jam
}

\author{
Eke-Ejiofor. J*, Owuno. F \\ Department of Food Science and Technology, Rivers State University of Science and Technology, Port -Harcourt, Nigeria
}

Email address:

joyekee@yahoo.co.uk(Eke-Ejiofor. J)

\section{To cite this article:}

Eke-Ejiofor. J, Owuno. F. The Pysico-Chemical and Sensory Properties of Jackfruit (Artocarpus Heterophilus) Jam. International Journal of Nutrition and Food Sciences. Vol. 2, No. 3, 2013, pp. 149-152. doi: 10.11648/j.ijnfs.20130203.19

\begin{abstract}
The potential of a nutritious fruit such as jackfruit (Artocarpus heterophilus) has remained largely untapped. Most tropical fruits can be processed and preserved in order to reduce post harvest loss in small scale operations using simple techniques. The proximate composition and sensory properties of jackfruit jam were investigated and pineapple jam was used as a control. Jackfruit jam was produced using the traditional open pan method. Proximate analysis showed protein content ranging from $0.19-1.12$, ash from $0.27-1.50$, vitamin $\mathrm{C}$ from $0.0037-0.0099$, total acid from $0.054-0.313$, $\mathrm{pH}$ from 3.35- 5.57 and ${ }^{\circ}$ Brix from $23-70 \%$. Result from Sensory evaluation using a five point hedonic scale to rate for color, aroma, taste, after taste, texture and general acceptability by untrained panelists indicated general acceptance of jackfruit jam. Results from sensory analysis showed that color ranged from 3.7-4.4, aroma from 3.7-4.4, taste from 3.8-4.6, after taste from 3.4-4.3 and general acceptability from 3.9-4.5, with jackfruit lower than the control in all cases, while texture ranged from 3.7- 4.3 and spreadability from 3.5-4.5 with jackfruit having a higher value in both cases. There was a significant difference at $(\mathrm{P}<0.05)$ in color, aroma, taste and general acceptability with control rated higher. While texture and spreadability showed no significant difference of $(\mathrm{P}>0.05)$. Assessors however scored jackfruit jam high for flavor and spreadability.
\end{abstract}

Keywords: Jackfruit, Jam, Chemical, Sensory, Properties

\section{Introduction}

Jam is a product made with whole fruit, cut into pieces or crushed. The fruit is heated with water and sugar to activate the pectin in the fruit (www.wikipedia.org).

UNE regulation (1974) defined jams as product formulated from a minimum fruit content of $40 \%$ (30\% for citric) and a final soluble solid content of $45^{\circ}$ Brix. Moreover, some additives such as citric acid or gelling agents, commonly pectin, can be added. In traditional jam manufacture, all the ingredients are mixed in adequate proportions and the mix is concentrated by applying thermal treatments at normal or reduced pressure to reach the required final soluble content.

Generally, jam is produced by taking mashed or chopped fruit or vegetable pulp and boiling it with sugar and water. The proportion of sugar and fruit varies according to the type of fruit and its ripeness, but a rough starting point is equal weights of each. When the mixture reaches a temperature of $104^{\circ} \mathrm{C}\left(219^{\circ} \mathrm{F}\right)$, the acid and the pectin in the fruit react with the sugar, and the jam will set on cooling. However, most cooks work by trial and error, bringing the mixture to a "fast rolling boil", watching to see if the seething mass changes texture, and dropping small samples on a plate to see if they run or set (Berolzheimer et al., 1959).

An alternative in jam formulation is to use previously dehydrated fruit, thus reducing the concentration requirements (Shi et al, 1996). In this sense, osmotic dehydration allows us to obtain fruit products that have good flavor, aroma and nutritional content and small mineral and vitamin losses (Dixon \& Jen, 1977; Lenart \& Flink, 1984; Ponting, 1973).

Fruits with naturally high pectin content including citrus fruit such as limes and lemons, berry fruit such as cranberries, loganberries, redcurrants and blackcurrants, and tree top fruit such as quinces and apples including apricots were commonly used in producing jam (Burkill, 1997).

Jackfruit (Artocarpus heterophyllus L.) belongs to the family Moraceae. It grows abundantly in Bangladesh, India and in many parts of Southeast Asia (Rahman et al., 1999). 
In Bangladesh it is commonly referred to as 'the poor man's food' (Rahman et al., 1995). It is cultivated in some of the countries in the evergreen forest zone of West Africa (Burkill, 1997). In Nigeria, its cultivation has not been encouraged, though it is found in the south-coastal parts of the country where it grows wild or semi-conserved. Jackfruit has been reported to contain high levels of protein, starch, calcium and thiamine (Burkill, 1997). It is also rich in energy, dietary fiber which makes it a good bulk laxative. The fiber content helps to protect the colon mucous membrane by decreasing exposure time and as well as binding to cancer causing chemicals in the colon (Morton, 1987) as well as mineral and vitamins. In addition, it is one of the rare fruits that is rich in B-complex group of vitamins. It contains very good amounts of vitamin B-6 (pyridoxine), niacin, riboflavin, and folic acid. The pulp and seeds of jackfruit are considered as a cooling and nutritious tonic.

Nevertheless, it contains no saturated fats or cholesterol, making it one of the healthy fruits to savor. The pulp of the ripe jackfruit may be eaten fresh or incorporated into fruit salad. The seeds are eaten when boiled or roasted.

The use of Jackfruit is limited in this part of the country and therefore calls for research into its composition and other means of utilization and value addition due to its high perishable nature. The objectives of this study is

To prepare and determine the physicochemical and sensory properties of jam produced from jackfruit.

\section{Materials and Methods}

\subsection{Materials}

Sugar was purchased from Abuloma market, unripe oranges for pectin production were collected from the Crop Science farm, Rivers State University of Science and Technology (RSUST), Nkpolu, Port Harcourt and Jackfruit was harvested from a farm in Anogu village, Umuoji in Anambra State, Nigeria.

\subsection{Chemicals}

Chemicals used were collected from the analytical lab, department of Food Science and Technology, Rivers State University of Science and Technology (RSUST) and were all of analytical grade.

\subsection{Methods}

Pectin was extracted from 8 unripe oranges. 2 cups of water and four table spoonful lemon juice were mixed together and gently boiled for 10 minutes. It was allowed to cool and the liquid was filtered. $20 \mathrm{ml}$ of the liquid was used in the preparation of jam.

\subsection{Production of Jam}

The jackfruit was cut open and the pulps was extracted from the fibre. $300 \mathrm{~g}$ of the pulp was weighed and cut into pieces and boiled in $900 \mathrm{ml}$ water, $300 \mathrm{~g}$ sugar. $18 \mathrm{~g}$ citric acid and $20 \mathrm{ml}$ pectin for 10 to 15 minutes using the open pan method, which gives a traditional flavor, with some caramelization of the sugars (Garcia-Martınez et al, 2002).It was then removed from heat and allowed to cool. After cooling, it was blended into paste.

\subsection{Proximate Analysis of Jackfruit Jam}

Total available carbohydrate, Crude protein, moisture content ash and vitamin were determined by (AOAC, 1990). Total soluble solids (Brix\%) was determined using a sugar refractometer. $\mathrm{pH}$ was determined using a digital $\mathrm{pH}$ meter (Model PHS-2F). Total Titratable Acidity (TTA) was determined by the (AOAC 1990) method. Sensory evaluation was done using a 5 point hedonic scale to rate for color, taste, texture, after taste, aroma, spreadability and overall acceptability as described by Larmond (1977). Statistical analysis was done using analysis of variance (ANOVA) and means were separated by the Least Significant Difference (LSD) procedure (Steel and Torrie, 1980).

\section{Results and Discussion}

Table 1 shows the chemical properties of fresh jackfruit, jackfruit jam and pineapple jam used as control. Moisture content ranged from $23.29 \%-73.60 \%$ with the control having the least value. The difference in moisture between the unprocessed jack fruit is expected because of the heating process involved in the cause of moisture evaporation. Jackfruit jam had a higher moisture content than pineapple jam. Moisture has a great impact on the shelf life of products. There was a significant difference $(\mathrm{P}>0.05)$ in moisture between the pineapple jam and jackfruit jam. Protein content increased with ingredients from $0.185 \%-0.457 \%$. There was a significant difference $(\mathrm{P}<0.05)$ in protein content between pineapple and jackfruit jam.

Carbohydrate ranged from $13.60 \%$ - $48.48 \%$ with jackfruit jam been lower than pineapple jam.

Processing increased carbohydrate as moisture reduced in the unprocessed state. Protein content ranged from $0.19 \%$ - $1.12 \%$ with pineapple jam having the lowest and jackfruit jam having the highest of the products. Ash content of $-0.15 \%$ and $0.27 \%$ was recorded for control and jackfruit jam spread respectively. Vitamin C content ranged from $0.0037 \%$ $-0.0069 \%$ with jackfruit jam and pineapple jam having the lowest and highest respectively. Total acidity ranged from $0.054 \%-0.313 \%$, with Pineapple jam having the lowest and jackfruit jam having the highest value.

$\mathrm{pH}$ ranged from 3.35- 5.57, with jackfruit and pineapple jam showing no difference. The $\mathrm{pH}$ of jam is an important factor to obtain optimum gel condition. The $\mathrm{pH}$ in the present study is slightly lower than that reported by Imtiaz Hussain and Iftikhar Shakir (2010) for apricot and apple jam. Sugar as oBrix ranged from $23-70 \%$ with the control 
having the highest. The sugar present in jam comprise natural and added sugar and is an important preservative. The proportion of sugar to fruit varies according to the type of fruit and its ripeness, but a rough starting point is equal weight of each (www.wikipeadia.org).

Table 1. Chemical Analysis of Jackfruit and Jackfruit Jam

\begin{tabular}{lcccccccc}
\hline Sample & moisture & CHO & protein & Ash & Vit C & Total acidity & pH & Sugar \%Brix \\
\hline Raw fruit & 73.60 & 13.92 & 1.12 & 0.43 & 0.0099 & 0.058 & 5.57 & 23 \\
Jackfruit jam & 24.60 & 30.90 & 0.46 & 0.27 & 0.0037 & 0.313 & 3.36 & 40 \\
Control & 23.29 & 48.48 & 0.19 & 1.50 & 0.0069 & 0.054 & 3.35 & 70 \\
\hline
\end{tabular}
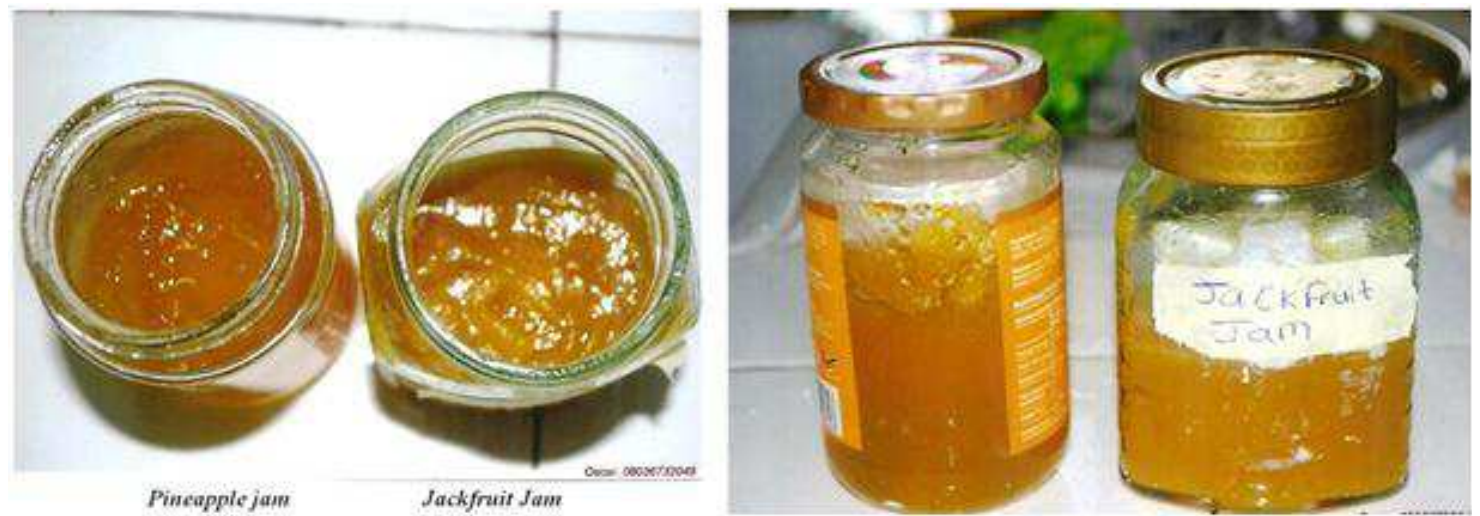

Table 2. Mean sensory evaluation of Jackfruit jam and control (pineapple)

\begin{tabular}{cccccccc}
\hline Sample & Colour & Aroma & Taste & After Taste & Texture & Spreadability & General Acceptance \\
\hline Jackfruit jam & $3.7^{\mathrm{b}}$ & $3.7^{\mathrm{b}}$ & $3.8^{\mathrm{b}}$ & $3.4^{\mathrm{b}}$ & $4.3^{\mathrm{a}}$ & $4.5^{\mathrm{a}}$ & $3.9^{\mathrm{b}}$ \\
Control & $4.4^{\mathrm{a}}$ & $4.4^{\mathrm{a}}$ & $4.6^{\mathrm{a}}$ & $4.3^{\mathrm{a}}$ & $3.7^{\mathrm{a}}$ & $3.5^{\mathrm{a}}$ & $4.5^{\mathrm{a}}$ \\
\hline
\end{tabular}

Table 2 shows the sensory evaluation of jackfruit jam and pineapple jam used as control. Color by physical examination and flavor ranged from $3.7 \%-4.4 \%$ with jackfruit jam having the lowest and pineapple jam having the highest in both cases.

Color is an important sensory attribute on which the consumer preference depends. Taste ranged from 3.8\% $4.6 \%$ with jackfruit as lowest and control as highest. After taste ranged from $3.4 \%-4.3 \%$ with jackfruit jam as lowest and control as highest. Texture and spreadability ranged from $3.7 \%-4.3 \%$, and $3.5 \%-4.5 \%$ respectively with the control sample having the least and jackfruit jam the highest in both cases. Good jam has a soft even consistency without distinct pieces of fruit, a bright color, a good fruit flavor and a semi-jellied texture that is easy to spread but has no free liquid (Berolzheimer R et al., 1969).

General acceptability ranged from 3.9\% - 4.5\% with jackfruit jam as lowest and the control having the highest.

Appearance and color by physical examination reduced from $4.4 \%-3.7 \%$. There was a significant difference between the pineapple jam and jackfruit jam. Taste reduced from $4.6 \%-3.8 \%$. There was a significant difference between the spread. Texture/mouth feel increased from 3.7\% - $4.3 \%$ with a significant difference between the jackfruit jam and pineapple jam.

Aroma reduced from $4.4 \%-3.7 \%$ with a significant difference between jackfruit jam and pineapple jam. Spreadability increased from $3.5 \%-4.5 \%$ with a significant difference between jackfruit jam and pineapple jam. General acceptability reduced from 4.5\% - 3.9\% with a significant difference between jackfruit and pineapple jam. The flavor is similar to a tart banana. Jackfruit bulbs have unique flavor and sweet taste (Morton, 1987)

\section{Conclusion}

Results of the present study have shown that jackfruit has a good amount of protein when raw and when further processed into jam irrespective of it been a fruit and also a high total acidity, showing the products ability to store for a longer time. Therefore, jackfruit with its high fiber content, nutrient compositions and sensory attributes can successfully be used for the preparation of jam to add value to the fruit, reduce post harvest losses due to its perishability as a result of its high moisture content as revealed in the study of $73.60 \%$, as well as create variety.

\section{References}

[1] AOAC (1990). Association of Official Analytical Chemist Official Methods of Analysis. Washington, DC. 
[2] Berolzheimer, R, Bentley, M., Flora R. (1959) The American Woman's Cook Book. Consolidated Book Publishers, Inc, Cornell University Press. pp. 10-22

[3] Burkill, H.M., (1997). The Useful Plants of West Tropical Africa. Vol. 4, 2nd Edn. Royal Botanic Gardens, Kew, pp: 160-161.

[4] Dixon, G. M., \& Jen, J. J. (1977). Changes of sugars and acids of osmovac dried apple slices. Journal of Food Science, 42, 1126-1127.

[5] Garcia-Martınez, E. , Ruiz-Diaz, G., Martınez-Monzo, J., Camacho, M.M., Martı'nez-Navarrete, N., Chiralt, A.(2002). Jam manufacture with osmodehydrated fruit. Food Research International 35;301-306

[6] Imtiaz Hussain and Iftikhar Shakir(2010): Chemical and Organoleptic Characteristics of Jam prepared from Indigenous Varieties of Apricot and Apple. World Journal of Dairy and Food Sciences 5(1):73-78.

[7] Larmond, E., 1977: Laboratory methods for sensory Evaluation of food, Canda Pept Agric-Pub.

[8] Lenart, A., \& Flink, J. M. (1984). Osmotic concentration of potato II-spatial distribution of the osmotic effect. Journal of Food Technology, 19, 45-65.

[9] Morton, J. (1987). Fruits of Warm Climates. Miami, Florida.

$<$ http://www.hort.purdue.edu/newcrop/morton/jackfruit_ars. html>.

[10] Ponting, J. D. (1973). Osmotic dehydration of fruitsrecent modifications and applications. Process Biochemistry, $8,18-20$.

[11] Rahman, A.K.M.M., E. Huq, A.J. Mian and A. Chesson (1995). Microscopic and chemical changes occurring during the ripening of two forms jackfruit (Artocarpus heterophyllus L). Food Chem., 52: 405-410.

[12] Shi, X. Q., Chiralt, A., Fito, P., Serra, J., Escoin, C., \& Gasque, L. (1996). Application of osmotic dehydration technology on jam processing. Drying Technology, 14(3 \& 4), 841-857.

[13] Steel, R.G.D and Torrie, J.H (1980): Principles and procedures of statistics. MC Graw Hill Pub. Comp. Inc. New York UNE (Una Norma Espanola). (1974). 34-074-74.

[14] Wikipedia (2012) www.wikipedia.org/jackfruit retrieved September 24, 2012 